\title{
NÍVEIS DE SIGNIFICADOS DA APRENDIZAGEM CIENTÍFICA DO ESTUDANTE: EM DIREÇÃO À ELABORAÇÃO DE UM INSTRUMENTO ANALÍTICO INSPIRADO EM UMA LEITURA PEIRCEANA
}

\section{STUDENT MEANING LEVELS OF SCIENTIFIC LEARNING: TOWARDS THE ELABORATION OF AN ANALYTICAL TOOL INSPIRED BY A PEIRCEAN READING}

\author{
Carlos Eduardo Laburú* \\ Universidade Estadual de Londrina $(*)$ \\ Departamento de Física \\ E-mail: laburu@uel.br
}

\begin{abstract}
Resumo
Este estudo faz reflexões teóricas a respeito da questão do significado, tendo como foco de interesse uma possível aplicação à educação científica. Trafegando por diversas visões desse termo, o estudo realça o ponto de vista semiótico e se concentra no conceito de interpretante da teoria de Peirce. A partir de uma particular reformulação do conceito peirceano, o trabalho sugere um instrumento analítico que permita ao professor qualificar o alcance da formação do significado construído pelo estudante durante o ensino das ciências. Com as discussões que circunscrevem a proposta, espera-se que o estudo contribua também para um repensar do professor acerca do conceito abordado e que isto se traduza em implicações pedagógicas teoricamente mais fundamentadas.
\end{abstract}

Palavras-chave: aprendizagem científica, Peirce

\begin{abstract}
This study makes theoretical reflections about meaning, focusing on a possible interest by application it to science education. Passing by several visions of this term, the study highlight the semiotic point of view and focuses on the interpretant concept of Peirce's theory. From a particular reformulation of this peircean concept, the paper suggests an analytic tool that allows teacher classify the extent formation of students' meaning constructed during sciences teaching. With the discussions that circumscribe the proposal it is also expected that the study will contribute to teacher rethink the addressed concept and that this results into more theoretically grounded pedagogical implications.
\end{abstract}

Keywords: science learning, Peirce 


\section{INTRODUÇÃO}

Um dos objetivos da educação científica é a apreensão dos significados dos conceitos científicos em maior profundidade possível, em contraponto à memorização sem sentido e efêmera, onde ocorram aprendizagens de informações meramente literais e automáticas. Ao se atribuir significado para o que é ensinado no estudo das ciências, espera-se que se construam, não só conteúdos declarativos, mas procedimentos e valores a respeitar envolvidos com os conteúdos (ZABALA, 1998). Todavia, se a aprendizagem se der sem significado, a construção dos conceitos permanece superficial e pouco consciente, valores, atitudes e comportamentos desejados não se modificam, além de que procedimentos e atuações sobre o mundo tornam-se irrefletidos, conservando-se dissociados e sem um mínimo de articulação entre si. Em tal condição, o estudante, ao utilizar o conhecimento científico, o faz tão somente para dar cumprimento às circunstâncias escolares, sem chegar a entender o que realmente está dizendo e/ou realizando. No caso, a compreensão se manifesta basicamente de maneira mecanicista, com memorização de curto prazo, repetitiva ou imitativa. Para Coll (2002), o ensino deveria agir no sentido dos alunos aprofundarem e ampliarem os significados construídos nas situações de instrução. Entretanto, adverte que não é incomum o estudante atribuir ao conteúdo um significado muito diferente daquilo que o professor ensinou, o que acaba implicando em uma compreensão, muitas vezes, incoerente com o conhecimento científico.

O mecanismo e estrutura cognitiva através dos quais os aprendizes acessam o conhecimento e constroem significados têm sido o foco de pesquisas que procuram entender como promover a congruência entre as interpretações dos fenômenos e aquela da explicação científica. Disto se coloca para qualquer educador a importante questão do que se entende pelo termo significado. A saltar à vista, tem-se a afirmação de Vygostky (2000, p. 151) de que o significado, por ser um fenômeno de pensamento, deveria ultrapassar uma simples resposta para sua compreensão. A complexidade do termo começa a aparecer quando nos damos conta de que as experiências diretas de cada aprendiz em relação ao mesmo objeto, normalmente diferem, ainda que possam ter em comum o mesmo significado. Por sua vez, os sujeitos conseguem discernir o que o outro quer dizer com um signo particular, assim como sabem distinguir em que grau dois significados são idênticos ou diferentes. Como voltaremos a discutir, tal fenômeno ocorre quando relações similares de significados são mantidas na comunicação entre emissor e receptor, fazendo com que 
o signo transmitido adquira semelhante compreensão para ambos. Essa propriedade dos signos é, inclusive, sua maior peculiaridade. Através dela torna-se possível a passagem de um ato de pensamento de um sujeito para outro e tal ocorrência se mostra bem sucedida quando o receptor apreende todos os aspectos similares e relevantes do pensamento simbólico do emissor. Agora, se os ditos aspectos e relações em causa diferirem, também diferirá o significado do signo para cada um. E em razão da natureza de composição, hierarquia ou conexão associativa dessas relações, na prática a determinação do significado é difícil e as diferenças no uso dos signos por pessoas até do mesmo grupo social podem ser bem grandes. Vale apontar que, usualmente, a simbolização se torna guia para os nossos significados e sentimentos, e que ambos acompanham o signo indistintamente.

Conhecer a resposta para a questão colocada interessa a qualquer educador, já que um dos atributos de sua profissão é proceder de maneira que o aprendiz construa com significado o que está sendo ensinado. Restritos às características peculiares que envolvem o educador de ciências, dada a natureza do conhecimento com o qual trabalha, a preocupação em ensinar conceitos científicos, de maneira que adquiram um significado objetivo para o estudante, é um desafio permanente.

Diferentemente das linguagens empregadas em outros conhecimentos, com os signos da linguagem científica anseia-se apreender os fenômenos naturais, objetivando, através da ação, controlá-los. Como será aprofundado, em seu sentido mais geral, todo signo significa, isto é, possui significado, caso contrário torna-se mero estímulo imperceptível à cognição. Efetivamente, não existem signos sem significados e a dificuldade que se coloca é determinar que significados transmitem, portanto, que pensamento lhes veem associados e a que referente, ou, no que se aplica à ciência, a que objetos sensíveis se referem. Porém, o que vem a ser significado é um problema, não só para o educador científico, mas um dos maiores problemas de toda a ciência semiótica.

Com a preocupação centrada na aprendizagem dos conceitos científicos e no estabelecimento de parâmetros para caracterizar e estabelecer o significado aprendido por um estudante em processo de ensino, este trabalho reúne ponderações a respeito da formulação deste basilar conceito, com o objetivo de propor um construto teórico que permita qualificar analiticamente o significado 
adquirido por aprendizes, durante o processo de instrução científica. Frente a esse propósito, começamos com considerações mais abrangentes acerca do que se compreende por significado, procurando estabelecer suas primeiras reflexões e mostrando alguns dos seus sentidos. A seguir, tangenciamos as teorias da aprendizagem significativa e da multimodalidade representacional da educação científica com o objetivo de expor como esse conceito é por elas situado. Ainda que o assunto não se esgote nessas referências, a opção por elas se deve aos seus sentidos mútuos de significado como organização do conhecimento. Após essa exposição e tendo o construto teórico como meta, o significado é qualificado junto à teoria semiótica peirceana, que o denomina de "interpretante". Ainda que durante essa apresentação se adentre em abstratas conceituações semióticas, elas são necessárias não apenas para dar fundamento ao construto teórico proposto, como também para fazer ver sua inspiração e origem. Finalmente, motivada e sustentada pelas argumentações desenvolvidas, é introduzida a proposta do instrumento analítico para auxiliar a caracterização do significado atingido por um aprendiz, quando em processo de apropriação de conhecimentos científicos.

\section{OS SIGNIFICADOS DE SIGNIFICADO}

Normalmente, a intenção de quem comunica provê complexas definições a respeito do termo significado, dependendo dos propósitos especiais para o qual é usado. Em trabalho seminal publicado em 1923, Ogden e Richards afirmam que as expressões dos filósofos não são confiáveis quando fazem menção ao referido termo. Os dois autores listam dezesseis definições de significado que consideram mais representativas, e que foram levantadas por eles a partir do emprego feito por estudiosos quando tratavam desse assunto. Passemos a resumir as definições encontradas, sendo que um maior esclarecimento para algumas delas poderá ser diretamente consultado na obra de Ogden \& Richards (1989), enquanto para outras, de maior interesse para o trabalho, foram deixadas seções separadas no manuscrito para maior aprofundamento, procurando, inclusive, complementar com considerações mais atualizadas. Tem-se então o termo significado usado como: I) Uma propriedade intrínseca; II) Uma única e não analisável relação com outras coisas; III) Outras palavras anexadas a uma palavra no dicionário; IV) Conotação dada à palavra; V) Uma essência; VI) Uma atividade projetada no objeto; VII) Um resultado pretendido ou uma volição; VIII) Lugar de algo em um sistema; IX) As consequências práticas de algo em nossa experiência futura; X) Consequência teórica envolvida ou implicada em uma declaração; XI) Emoção surgida de algo; XII) 
Aquilo que um signo realmente associa através de uma relação escolhida; XIII) (a) Um efeito mnêmico de um estímulo. Associações adquiridas; (b) Alguma outra ocorrência para a qual são apropriados os mnêmicos efeitos de qualquer ocorrência; (c) Aquilo que é interpretado pelo signo como devendo ser; (d) Qualquer coisa sugerida; no caso dos símbolos, aquilo a que eles realmente se referem para a pessoa que os usam; XIV) Aquilo a que o usuário do símbolo deveria estar se referindo; XV) Aquilo a que o usuário do símbolo acredita estar se referindo; XVI) Aquilo a que o intérprete de um símbolo (a) se refere; (b) acredita estar se referindo; (c) acredita que o usuário do símbolo esteja se referindo (op. cit, p. 186).

Ogden e Richards juntam essas definições em grupos, visto entenderem que elas nem sempre são claramente separáveis e independentes. Assim, na primeira definição o significado é usado no sentido de alguma coisa, uma propriedade intrínseca ou uma relação especial não analisada. Dessa forma, algo que possua essas características terá significado. A definição III, a mais amplamente empregada, segundo os autores, tem indubitável valor no domínio da filosofia, já que pode ser empregada com a definição $\mathrm{V}$ que mantém vínculo com o realismo crítico. $\mathrm{O}$ termo conotação em IV tinha até então sua adoção ligada aos estudiosos da prática discursiva de tradição lógica, podendo o símbolo ter dois significados: 1) Conjunto de coisas sobre as quais o símbolo é capaz de ser aplicado corretamente, em que os membros desse conjunto são ditos denotados ou indicados pela palavra; e 2) As propriedades usadas para determinação da aplicação do símbolo e reconhecidas como sua conotação ou simplesmente seu significado.

Em relação à definição $\mathrm{VI}$, o significado como a atividade projetada ao objeto, proclama uma maneira de expressar visões similares ao mnêmico efeito de um estímulo por associações adquiridas (XIII). A definição VII derivou-se do estudo das seguintes frases: "They meant no harm; He means well; I meant to go; What I meant was what I said; A mechanistic universe is without meaning" (ibid., p.191). No entender de Ogden e Richards, quando for possível substituir as palavras em itálico por intenção ou pretender ("intend"), fica claro que um tipo diferente de "significado" é expresso quando isto não puder ser feito. A definição VIII especifica que alguma coisa tem significado quando vier relacionada a outras coisas ou pertencer a um sistema (ibid., p. 196). A definição IX é principalmente associada aos pragmatistas, dado reconhecer o significado em termos de consequências práticas. Nesse sentido, o significado de qualquer proposição pode sempre ser reduzido para alguma consequência particular de nossa experiência prática futura, seja 
ela passiva ou ativa. As definições $\mathrm{X}$ e XI dirigem-se, respectivamente, àqueles que em suas conversas introduzem a palavra significado como sinônimo de envolvimento ou implicação lógica (ibid., p. 198), ou quando a empregam de maneira puramente emotiva ou de forma estilista. No último caso, um exame detalhado do seu sentido é quase equivalente a uma investigação de "valores" fundada em aspectos afetivo-volutivos (ibid., p. 199). Dessa forma, palavras como Deus, liberdade e amor deixam uma trilha afetiva de significados, pois carregam conotação emocional. A definição XII pressupõe assumir, generalizadamente, que qualquer evento está conectado a outro de forma causal, temporal ou de qualquer outra maneira. Ao tomar um evento como um sinal de uma dessas relações, haverá outro evento que gerará seu significado. Assim, os efeitos de acender um fósforo, por exemplo, é a produção de uma chama, a fumaça produzida, a cabeça do fósforo vindo a cair, ou, meramente, o barulho de raspar. Neste último caso, o efeito real está no significado do barulho tratado como um sinal, ou seja, o próprio sinal de raspar é o de acender o fósforo. Logo, o significado deriva de uma associação relacional entre causa e efeito (p. 199).

A passagem da definição XII para a XIII merece que se ressalte que todo pensamento e referência são adaptações, devido a contextos psicológicos que provocam interligação dos elementos de contextos externos. Por exemplo, uma experiência alimentar agradável ou desagradável surge do resultado do contexto visão-pegar-saborear. Essa simples ilustração é peculiar de um tipo de interpretação, cujo contexto que nos afeta no passado e sua mera recorrência posterior, mesmo que ocorra parte dela, causa-nos uma reação semelhante à reação passada. Em outros termos, alguma parte de um estímulo que venha do mesmo contexto do estímulo original é sinal suficiente para evocar ou excitar um processo mental que gera significado de mesmo pensamento. Para Ogdan e Richards (op. cit., p. 205) não há diferenciação entre as definições XII e XIII-b quando as interpretações forem verdadeiras. O significado de um signo adequadamente interpretado da definição XIII-b é o de estar realmente associado por uma relação sígnica. Mas, para falsas interpretações, os significados de XII e XIII-b são diferentes. Quando isso acontece, não há necessidade de qualquer correspondência com uma teoria da verdade, desde que um pensamento adequado não tenha com aquilo que é pensado um correspondente com o fato ou evento, como trata a definição XII, mas algo que lhe é semelhante.

As três definições finais dizem respeito ao que o falante tem em mente e como isso se relacionaria com o que o ouvinte deveria entender, ou com aquilo que ele entenderia de fato. Dizem respeito 
também ao significado intencionalmente velado na expressão do falante, ou com o significado não desejado por ele. Particularmente, a definição XIV estabelece que o significado seja consequência do entendimento de que um símbolo somente se torna bem utilizado quando aquilo que o usuário do símbolo se referiu causa pensamentos similares em qualquer intérprete.

Por detrás das definições anteriores se encontram muitas das noções que serão desenvolvidas e daí a importância dessa primeira recuperação dos conceitos envolvidos com elas. Situado isso, lembramos que é ordinário a raiz do problema do que seja significado vir da superstição de que as palavras, de alguma maneira, partem das coisas ou implicam sempre as coisas que Ihes correspondam (OGDEN \& RICHARDS, 1989, p. 14). Não obstante, por ser um tipo particular de signo, a palavra não precisa ter qualquer similaridade com o que significa. Contra a ideia simplista de que as palavras são nomes das coisas e as próprias coisas são os significados das palavras, Saussure fez notar que essa concepção decorre do pressuposto errôneo das ideias serem anteriores às palavras (FIDALGO; GRADIM, 2005, p. 82); posição igualmente contestada e reforçada por Vygotsky quando declara existir relação direta entre linguagem e pensamento (OLIVEIRA, 1993). Perceba-se que, com São Tomas de Aquino, já surge uma das primeiras identificações, via signos formais, de toda a vida psíquica, com os processos semióticos (FIDALGO; GRADIM, 2005, p. 40).

No momento em que rotineiramente declaram-se frases do tipo "isto não tem significado", "qual o significado disto?", "aprendizagem com significado", está-se a associar o termo significado basicamente com compreensão, sentido, saber algo. Todavia, é comum, nestes casos, o termo estar associado a variados graus de compreensão, indo desde uma simples concepção aproximada ou mesmo errônea do conhecimento (CLEMENT, 1982) até uma conceituação profunda. Diferentemente da palavra conceber, a referência a conceituar sempre expressa um entendimento completo e não uma vaga noção do que se está a pensar. Indica uma ideia corretamente estruturada que $\mathrm{o}$ ato de aprendizagem conseguiu apropriar-se. Nesta situação, a palavra conceituar é empregada concomitantemente com o termo significado, querendo dizer que o conhecimento tem sentido coerente e preciso em relação ao saber oficial. Ou seja, dizer que se possui o significado é equivalente a afirmar que o conceito ensinado foi apropriado pelo aprendiz. 
Outra possibilidade semântica que poderia ser facilmente associada ao termo significado é entendimento. Gardner (1995, p. 162) comenta que a maioria dos educadores tem dificuldade em definir exatamente a natureza do entendimento ou mesmo nem sabe como documentar se ele foi ou não obtido. Para ele, um indivíduo "entende" quando for capaz de aplicar conhecimentos, conceitos ou habilidades adquiridas em algum tipo de ambiente educacional, em novo exemplo ou situação em que este conhecimento for relevante. Por inferência, o indivíduo não entende se não é capaz de aplicar esse conhecimento, ou o utiliza de maneira inadequada em confronto com uma situação desconhecida e não recorrente. Segundo Gardner, a demonstração de entendimento se faz através do "desempenho". É por meio do desempenho de um aluno que se pode apreciar e apreender o seu entendimento. Para o autor, não se pode saber se o aprendiz compreende um princípio de uma ciência estudada, a menos que ele apresente um desempenho relevante de entendimento (ibid., p. 165), e isto implica atuar com sucesso nas diversas tipologias do conteúdo, como o conceitual, procedimental e atitudinal (ZABALA,1998, p. 30), particularmente relevantes para o ensino das ciências. Portanto, da possível vinculação entre entendimento e significado pode-se depreender uma forma de avaliá-lo.

Voltando para a semiótica saussureana, encontramos em Prieto (1973, p. 10) a designação de significado como a classe formada pelas operações que um determinado sinal executa, isto é, as mensagens que podem ser transmitidas por meio dele e que constitui sua utilidade. Saussure diferencia significante, significado e significação. O primeiro tem a ver com a parte material do signo, o segundo com o conceito ou conteúdo vinculado pelo primeiro, sua imagem mental (COELHO NETTO, 2003, p. 20). No entender de Barthes (1972, p.46), Saussure notou bem a natureza psíquica do significado ao denominá-lo conceito. Assim, o significado da palavra boi não é o animal boi, mas sua imagem psíquica ou mental, como assegura Coelho Netto (op. cit.). Por sua vez, diferentemente do que se possa pensar à primeira vista, significação não é sinônimo de significado. Na esteira do significante, vem a imagem mental ou o conceito do significado, sendo que a significação se dá pela união entre certo significado com certo significante (COELHO NETTO, 2003, p. 22). Enquanto o significado está no domínio da linguagem, a significação está no da fala. Em outras palavras, enquanto a significação de um signo é uma questão individual, localizada no tempo e no espaço, o significado depende apenas do sistema instituído socialmente, e sob este aspecto está antes e acima do ato individual (ibid., p. 23). 


\subsection{Significados Denotativo e Conotativo}

A questão da significação conduz à consideração dos fenômenos de denotação e conotação de um signo, o que permite avançar a definição IV de Ogdan e Richards (1989). Para estes autores, o termo conotação foi frequentemente usado no mesmo sentido de compreensão (ibid., p. 188). No entanto, conotação e denotação são conceitos atualizáveis junto a uma mais aprofundada apreciação semiótica.

Antes de introduzi-la, porém, é preciso adiantar que um signo sempre é constituído por uma correlação codificada mútua, arbitrária e convencional entre elementos de um plano da expressão (significante) e de um plano do conteúdo (significado). Posto isto, dizemos que um signo é conotativo quando o seu plano da expressão se constitui de outro signo, cujo significado lhe corresponde em segunda instância. Caso o significado se dê em primeira instância fala-se em denotação. Nesta se considera uma relação codificada unívoca ou direta, em que há uma primeira forma precisa de relacionamento entre expressão e conteúdo (COELHO NETTO, 2003, p. 37), enquanto naquela a relação é vaga ou indireta. Assim, o que constitui uma conotação enquanto tal é o fato da mesma se instituir de maneira "parasitária" à base de um código precedente, não podendo ser veiculada antes de o conteúdo primário ter sido denotado (ECO, 2003, p. 46). Na passagem de um signo denotativo para um conotativo não há simples substituição de significado. O significado denotativo permanece no signo agregado ao seu significante, e a este conjunto se acrescenta outro novo significado. É exatamente porque o significado denotativo permanece no signo que surge a ambiguidade de mensagens que, conforme o contexto, assumirá uma ou outra significação (COELHO NETTO, 2003, p. 25). O significado da unidade cultural de primeira instância, do qual se compõe e identifica a marca denotativa, é, portanto, a base para conotações sucessivas. Barthes (1972, p.96) coloca que a relação de primeira instância denotativa entre um significante e significado amplia-se para uma segunda instância conotativa de significante e significado quando o primeiro par significante/significado denotativo incrusta-se como componente subjacente do significante segundo, que permanece associado ao novo significado de instância semelhante. Assim, a significação é um processo entre pares significantes/significados num devir infinito de significantes e significados, de denotações e conotações. 
Portanto, na marca conotativa buscam-se as intenções, os sentidos possíveis que o objeto se apresenta à mente e por ela é entendida, ou as propriedades que podem ser atribuídas ao denotado, que, contrariamente, representa a classe e a extensão de todos os objetos que o signo possa se referir. O signo remete, quanto ao seu denotado, para um significado, e quanto aos seus sentidos possíveis ou intenções, para as possíveis conotações ou propriedades que podem ser atribuídas ao denotado do signo (ECO, 1985, p. 132, 133). Para entender de maneira mais concreta todas essas colocações, vejamos que num primeiro momento um casaco de pele denota uma proteção ao frio e também remete, num segundo momento, a um valor antropológico e social de significação. Neste exemplo, o objeto adquire um sentido para além do seu sentido funcional, sendo possível uma estratificação de sentidos (FIDALGO, 1998, p.86). Existem, em outras palavras, sentidos primeiros, sentidos segundos assentes sobre os primeiros, sentidos assentes nos segundos etc. O sentido aparece composto de camadas sucessivas de sentidos ou múltiplos níveis de significação.

\subsection{Significado como organização do conhecimento em rede}

Antes da passagem para a conceituação peirceana, foco do trabalho, introduzamos, sinteticamente, a concepção que se encontra por detrás de certos referenciais teóricos ligados à psicologia cognitiva e à educação científica que associam o termo significado com organização do conhecimento em rede. Para esses referenciais, tal associação é tangencial, diferentemente do caso específico da disseminada teoria da Aprendizagem Significativa, que, como se vê, até carrega o termo explicitamente em sua denominação.

Diferentes pesquisadores em psicologia cognitiva esforçam-se para entender a forma pela qual o conhecimento é representado. De acordo com Sternberg (2008), um modelo mais antigo em uso hoje em dia entende o conhecimento em termos de representação de uma rede semântica. Uma rede semântica é uma teia de elementos de significados constituída por nós que, muitas vezes, representam conceitos. Estes últimos são a unidade fundamental do conhecimento simbólico responsáveis pela produção de ideias a respeito de algo, de modo a oferecer um meio para entender o mundo. A junção entre os nós forma uma rede de relações onde são criados categorias e atributos, que, basicamente, proporcionam um meio para organizar conceitos (STERNBERG, 2008 , p. 263, 270, 271). O significado de um conceito é consequência, então, da relação com 
outros conceitos, bem como de relações entre atributos e categorias contidos em um conceito. Na representação em rede semântica, um indivíduo constrói, com o passar do tempo, uma base de conhecimento acerca de um conceito, conforme mais informações forem adquiridas. $\mathrm{O}$ significado que se tem de um conceito específico como sabiá, por exemplo, depende, em parte, da relação deste conceito com conceitos mais gerais e fundamentais, como pássaros e coisas vivas. À medida que na rede se passa do geral para o específico, a informação torna-se cada vez mais singular e aprendemos que sabiá é um pássaro e que é, em parte, marrom. A confrontar esse modelo, tem-se a rede conexionista. Nesse caso de rede o significado vem como resultado de conexões. Por meio da ativação de algumas conexões, o significado é construído. Diferentemente da rede anterior, onde o processamento da construção do conhecimento se faz de modo serial, na conexionista ele acontece em paralelo (ibid. p. 283). Grosso modo, o importante a realçar da formação do significado em rede, é a sua visão de conhecimento mentalmente organizado, criando estruturas ou esquemas baseados em significados de conceitos relacionados (ibid. p. 274).

Na educação científica e matemática encontram-se trabalhos que apoiam suas ações pedagógicas nessa visão. Para eles, o ato cognitivo é uma questão igualmente de estabelecimento de conexões entre ideias do que será aprendido. No trabalho de Hiebert e Carpenter (1992), por exemplo, o conhecimento é constituído por representações internas ou mentais que se conectam, formando redes de conhecimento. Para entender um conceito ou procedimento é preciso que a representação interna do estudante faça parte de um sistema simbólico de conhecimento. Durante a construção deste, a natureza, o número, a intensidade, o status ou relevância e relações de composição hierárquicas das conexões engendradas pela representação interna podem determinar com que extensão e profundidade o significado está sendo proporcionado. Sob essa óptica, as referências em educação científica e matemáticas referidas de multimodos e múltiplas representações (YORE; HAND, 2010; WALDRIP et al., 2010) colocam que as diferenças nas habilidades dos aprendizes em usar, reconhecer, estabelecer, reunir e hierarquizar conexões entre múltiplas representações de um conceito podem ser analisadas em termos das diferentes redes internas de conhecimento formadas frente ao tipo específico de instrução recebida (PATTERSON; NORWOOD, 2004, p. 7). Por meio da multimodalidade representacional e múltiplas representações se oportuniza que os estudantes criem representações mentais dos conceitos que os ajudem a formar corretas redes de conexões internas a respeito do conhecimento. Com isso, vislumbra-se a possibilidade deles alcançarem níveis cognitivos mais elevados em seus pensamentos (ibid., p. 8), 
ou seja, maior compreensão. E é pelo uso intencional de resemiotizações e negociação das transformações semióticas que se leva à construção de conexões para instaurar significâncias, como coloca Steinbring (2006, p. 63). Os aprendizes, ao criarem conexões referenciais entre elementos e estruturas correspondentes em diferentes representações, estão a construir vinculações nas e entre as diferentes representações, e, por esse meio, são capazes de adquirir um mais profundo entendimento (HAND et al., 2009, p. 227).

Em continuidade a essa linha de pensamento, em que conceitos organizados em rede são condição para a formação de significados, situa-se a teoria da Aprendizagem Significativa. Nas palavras do idealizador da teoria, "o significado, propriamente dito, é um produto do processo de aprendizagem significativa" (AUSUBEL et al., 1980, p. 38) e esta é um processo pelo qual uma nova informação (um novo conhecimento) relaciona-se de forma não arbitrária e substantiva (não literal) à estrutura cognitiva do indivíduo (ibid., p. 34). Não arbitrariedade ocorre quando um material potencialmente significativo relaciona-se de maneira não fortuita com alguns conhecimentos pré-existentes especificamente relevantes chamados subsunçores (imagem, símbolo, conceito, proposição etc.). Substantividade ocorre se o que for incorporado à estrutura cognitiva não se limitar às palavras precisas usadas para expressar a nova ideia, mas incorpora a essência do que significam. Logo, um significado somente é aprendido em relação a outros necessariamente já assimilados (ibid., p. 137), ou seja, existentes. Assim, por exemplo, não se pode obter o significado da lei de Ohm se não existir previamente uma rede de significados como de corrente elétrica, de voltagem, de resistência elétrica e daí por diante (ibid., p. 36, 41). No entender de Ausubel, um significado é adquirido gradualmente e idiossincraticamente por cada indivíduo (ibid., p. 38). Tal aquisição se dá por integração cumulativa do conteúdo aprendido em uma edificação mental ordenada hierarquicamente, que envolve todo um arcabouço informacional armazenado anteriormente, e que, a partir de então, vem a constituir um novo conhecimento prévio (ibid., p. 139). A emergência de um significado real de algo, dependente da experiência de cada sujeito, que Ausubel define de significado psicológico, e é um produto do processo de aprendizagem significativa individual. Para que esse significado seja alcançado, tornando-se potencialmente significativo, dois pré-requisitos se fazem necessários. Um tem a ver com o significado lógico inerente e dependente apenas da natureza do material simbólico que vai ser estudado, o outro tem a ver com a disponibilidade de conteúdo significativo adequado na estrutura cognitiva do indivíduo (ibid., p. 41). 


\section{SIGNIFICADO NA PERSPECTIVA PEIRCEANA}

\subsection{Produção sígnica e significado}

O processo em que algo funciona como signo denomina-se semiose (MORRIS, 2010, p. 7). Esse processo tem sido habitualmente entendido desde Peirce de modo a envolver três fatores: aquilo que atua como signo, aquilo a que o signo se refere e o efeito sobre um intérprete, em virtude do qual a coisa em questão é um signo para esse intérprete. Esses três fatores da semiose podem chamar-se, respectivamente, o veículo sígnico (ou signo), o designatum e o interpretante. Enquanto o último não deve ser confundido com o intérprete, já que é um significado que dá sentido ao signo independentemente do sujeito interpretante (ECO, 2003, p. 58), como uma ideia, conceito, teoria ou explicação, o penúltimo pode ser pensado como o objeto, mas não necessariamente de existência real. O designatum trata de um referente do mundo, que pode ser um objeto físico, uma experiência, artefato, situação, contexto ou um processo (WALDRIP et al., 2010, p. 67) ou referente qualquer inexistente como um ser mitológico. Assim, sendo o rosnar de um cão o signo, o ataque é o designatum, o animal a ser atacado, o intérprete, e a resposta preparatória deste, o interpretante (MORRIS, 2010, p.38). Como se vê, Peirce leva a noção de signo tão longe que o mesmo não precisa ter a natureza plena de uma linguagem como palavras, desenhos, diagramas, fotos ou explicações complexas tais como conceitos, teorias, definições, ideias etc., mas pode ser uma mera ação ou reação (p.ex., correr para alcançar alguém), uma simples emoção ou qualquer sentimento como a qualidade vaga de sentir ternura, desejo ou raiva. O signo é aquilo que dá corpo aos pensamentos, experiências, emoções, reações etc. e podem ser externados (SANTAELLA, 2005, p. 10). Consequentemente, os signos não produzem, como interpretantes, apenas pensamentos, mas sentimentos, percepções, ações, condutas e comportamentos de modo que mesmo no signo de caráter intelectivo, todos esses elementos estão nele embutidos, constituindo, igualmente, sua substância (SANTAELLA, 1995, p. 116). Há circunstâncias comuns e importantes em que as palavras, por exemplo, expressam ou excitam sentimentos, atitudes, emoções, misturando elementos lógicos com afetivos, estes penúltimos estritamente evitados na linguagem técnica ou científica (OGDA; RICHARDS, 1989, p. 148, 152).

Para Morris (2010, p. 9), um significado é compreendido de três maneiras, tendo em vista sua vinculação com as componentes da semiose mencionadas. É considerado como uma coisa entre 
outras, qualquer coisa bem definida e definitivamente localizada num lugar qualquer, podendo, então, ser procurado no designatum que assim se transforma num gênero específico de objeto real e singular nomeado de denotatum. Pode ser procurado no interpretante, que se transforma em um conceito ou ideia, habitando um âmbito específico de entidades mentais, cuja relação com os estados psíquicos de intérpretes individuais se torna muito difícil de determinar. Por fim, pode ser procurado no veículo sígnico. No entanto, para Morris, nenhuma dessas posições provou ser satisfatória. Enquanto termos semióticos, veículo sígnico, designatum e nem interpretante são capazes de ser definidos sem referência uns aos outros, posto que não representam existências isoladas, mas coisas ou propriedades de coisas em relações especificamente funcionais com outras propriedades. Um estado psíquico, ou mesmo uma resposta, não é, enquanto tal, um interpretante, porém, assim se converte na medida em que é um "dar-se-conta-de-algo" evocado pelo signo (ibid., p. 46). Morris entende que o significado, do ponto de vista semiótico, não está ligado a uma linguagem-coisa, como entidades existentes iguais a árvores, rochedos ou cores, conforme anteriormente comentado, mas que esses objetos e propriedades funcionam dentro do processo de semiose. Essa interpretação evita a crença de que o significado é, em princípio, pessoal, privado ou subjetivo. Os significados são inacessíveis de fora, porém os indivíduos conseguem de algum modo comunicar esses estados mentais privados através de sons, da escrita e de outros signos, e uma experiência subjetiva torna-se capaz de virar intersubjetiva. Apesar de cada experiência de cada sujeito não se encontrar em relação imediata com a respectiva experiência direta que o outro tem do objeto, isto não impede de um designar ao outro suas experiências por meio indireto de sinais, pois, em certas circunstâncias, um objeto que não pode ser diretamente experimentado, pode ser denotado (ibid. p.47). Aqui é preciso ter cuidado com as palavras. Uma vez que na ostentação de objetos, ou na experiência com eles, ideias são elaboradas para conhecê-los, isto porque os dados sensoriais brutos vêm desconexos e necessitam ser organizados com base em hipóteses cognitivas baseadas em experiências anteriores (ECO, 2003, p. 145). Ou, mais concretamente, a percepção primária de que tubarão e golfinho porquanto vivem na água são peixes é uma enganosa abdução vinda de uma percepção imediata carregada de observáveis que privilegiam certas associações de semelhança entre esses animais, mais do que outras.

Mas, como já se observou, em geral os sujeitos são capazes de decidir o que o outro quer dizer com um determinado signo e, portanto, se os significados que querem transmitir são ou não 
idênticos e seu grau de clareza. Tais condições se mantêm dependentes da existência das mesmas relações semânticas, sintáticas e pragmáticas entre os sujeitos, o que faz com que o signo adquira um significado comum para ambos. Não obstante, se as relações em causa diferirem, o significado do signo para cada um também diferirá.

Em razão das aludidas relações, na prática a determinação do significado é difícil e as diferenças no uso dos signos pelas pessoas, ainda que do mesmo grupo social, podem ser bem grandes. Por outro lado, é fundamental compreender que apesar da subjetividade de certas experiências, mesmo as relativas à semiose, qualquer signo tem potencialidade intersubjetiva e, consequentemente, possibilidade de uma determinação e comunicação objetiva e exaustiva do seu significado (MORRIS, 2010, p. 49). Na situação específica de engajamento do aprendiz com novos significados das ciências é esperado que ele reconheça as diferenças entre uma ideia ou conceito, as diferentes maneiras destes últimos serem representados, a relação dos mesmos com o fenômeno e a tecnologia que se referem, assim como, suas implicações sociais e ambientais. Porém, toda tentativa do aprendiz para entender ou explicar os conceitos científicos vincula-se a um trabalho representacional que se serve de recursos representacionais e cognitivos correntes do sujeito, a fim de dar sentido aos novos conceitos científicos a serem aprendidos. Com isso, novas, modificadas e originais representações precisam ser estabelecidas e interpretadas pelo aprendiz. Vir a conhecer o que conceitos e palavras como momento de inércia, mamífero, mitocôndria ou ligação covalente significam do ponto de vista da ciência exige que se vincule entendimento e saber fazer de apropriados recursos representacionais para que conexões cognitivas adequadas sejam estabelecidas entre o fenômeno científico e as considerações teóricas a respeito do mesmo (WALDRIP et al. 2010, p. 68).

Ora, aprender novos conceitos não é dissociável de como aprender a representá-los e do que significam suas representações. De fato, o mecanismo cognitivo de apreensão conceitual de um objeto, ou "noesis", não se separa da apreensão ou produção de uma representação, ou seja, "semiosis" (DUVAL, 2004, p. 14). A consciência individual é nutrida em cima dos signos, sendo que seu crescimento deriva deles, uma vez que vai refletindo sua lógica e leis (KUBLI, 2005, p. 503). O processo de significação se verifica quando existe um código e vemo-nos em frente daquele no instante em que um sinal não funciona mais como um simples estímulo, mas solicita uma resposta interpretativa por parte do destinatário (ECO, 2003, p. 6), resultando, pois, em um signo. 0 código 
se constitui através da função sígnica que surge da associação entre uma expressão e um conteúdo (ibid., p. 39). Desta forma, se não existe código, e este é cultural, apenas existe um sinal sem sentido.

As semióticas de Saussure e Peirce são teorias da relação semiótica entre símbolo e referência (ou significado), e entre o signo e a série de seus interpretantes, respectivamente. Para Eco (2003, p. 10), "o primeiro autor jamais definiu claramente o significado, deixando-o a meio caminho entre uma imagem mental, um conceito e uma realidade psicológica não circunscrita diversamente". Em compensação, sublinhou o fato de o significado ser alguma coisa relacionada à atividade mental de indivíduos no seio da sociedade. No que toca ao objeto (ou designatum), este também não é levado em consideração por Saussure, enquanto Peirce só o considera quando se discutem tipos particulares de signos, como os índices e os ícones, sendo eliminados no interior de uma teoria dos códigos. Mas, é preciso ver, que o interesse maior das teorias está nas possíveis combinações entre funções sígnicas. Esta é a razão para a exclusão do objeto, visto que o referente deixa de ser objeto-ocorrência para ser objeto-tipo, no sentido de pertencer à classe de todos os objetos possíveis a que o signo se refere e não a um objeto fatual particular (denotatum), como no primeiro caso. Desta forma, o objeto se torna algo muito semelhante ao conteúdo, logo, diz respeito aos interpretantes, na leitura peirceana (ECO, 2003, p. 50 e 51). Porém, mesmo podendo o referente ser o objeto nomeado ou designado por uma expressão, quando a linguagem é usada para mencionar estados do mundo, deve-se assumir, como princípio, que uma expressão não designa um objeto, mas veicula um conteúdo cultural pertencente a uma categoria abstrata, ou como afirma Peirce, um signo só pode ser explicado por outro signo. Sendo assim, o objeto do signo, que é o que o signo representa, só pode estar representado no signo porque o próprio objeto é também uma representação, isto é, um signo (SANTAELLA, 1995, p. 88).

Dizer, então, que um interpretante corresponde a um objeto real constitui uma falsa posição no entender de Peirce, pois enquanto código aceito por uma sociedade, o interpretante é o construto de um mundo abstrato, de existência cultural, constituindo o modo pelo qual uma sociedade pensa, fala e, enquanto fala, resolve o sentido dos próprios pensamentos por meio de outros pensamentos e estes por meio de palavras. Um aprendiz, ou a coletividade social em geral, quando pensa e fala consegue evoluir, expandir-se ou entrar em crise, e o interpretante modifica-se 
mesmo se o referente tem a ver com mundos impossíveis, como sucede nos textos estéticos ou nas asserções ideológicas.

\section{$1 \quad 3.2$ SIGNIFICADO PARA PEIRCE: A TRÍADE INTERPRETANTE}

Ao colocar o problema do que seja o significado de um conceito, Peirce (apud. SANTAELLA, 1995, p. 104) afirma que ele somente pode ser resolvido através do estudo dos interpretantes ou, mais propriamente, dos efeitos interpretantes dos signos. Peirce não fala especificamente em significado de um signo, mas em seu interpretante. Este é a parte constituinte do signo que afeta a mente, determinando ou criando-Ihe um efeito. Com tal conceito ele estabelece que o processo de significação é sempre contínuo e crescente, dirigindo-se para o conteúdo objetivo e interpretante final do signo numa regressão infinita (SANTAELLA, 1995, p. 85). O interpretante de uma representação só pode ser e não passa de outra representação. Em suas palavras, "o Signo e a Explicação constroem um outro Signo, e como a Explicação será um Signo, este exigirá provavelmente uma explicação aditiva, que tomada como o Signo já ampliado dará origem a um Signo mais vasto... que deverá chegar finalmente a um signo de si mesmo..." (sic) (PEIRCE apud. ECO, 2003, p. 59). Para Eco (op. cit.), o signo final de que fala Peirce não é realmente um signo, mas um campo semântico total, como a estrutura que conecta os signos entre si. Peirce vê a vida mental como uma imensa cadeia sígnica que vai dos interpretantes lógicos primeiros aos finais. Estes são os hábitos, as disposições para a ação, para a intervenção sobre as coisas, que converge toda a semiose. Toda a vida do pensamento tende a formar no Homem hábitos de ação prática, “... de agir de um certo modo todas as vezes que se deseja um certo tipo de resultado." (sic) (PEIRCE apud ECO, 1985, p. 145).

O fundamental a ser apontado é que essa contínua circularidade semiótica é condição normal da significação e que permite o uso comunicativo dos signos para referir-se a coisas. Refutar como teoricamente insatisfatória essa situação significa apenas, segundo tal entendimento, que não se compreendeu qual seja o modo humano de significar, o mecanismo através do qual se faz a história, a cultura e o modo pelo qual, definindo o mundo, se atua sobre ele, transformando-o (ECO, 2003, p. 60). 
As afirmações antecedentes indicam que o processo semiótico de significação peirceano decorre de uma posição pragmatista, posição esta que não entra em conflito com a aprendizagem de ciências. Isso por que a doutrina pragmatista alega, em essência, que uma concepção deve ser confirmada através dos seus efeitos práticos e de seus resultados. Toda concepção que um sujeito tem de um objeto vem da sua concepção dos efeitos que mostram influência prática sobre o objeto (PEIRCE, 1977, p. 291). Por Coelho Netto (2003, p. 87), consegue-se transpor, de imediato, essa posição peirceana para a conclusão de que o significado de um signo consiste em fenômenos experimentais. Vê-se isto quando Peirce $(1977$, p. 294) diz que um fenômeno experimental é o fato afirmado pela proposição de que a ação de uma descrição terá certa espécie de resultado experimental. Para ele, os resultados experimentais são os únicos capazes de afetar a conduta humana (ibid.). Assim, conforme Coelho Netto (2003, p. 87), ao significado de um signo, ou a soma dos fenômenos experimentais implicada nesse signo, é dado o alcance que esse fenômeno tem sobre a conduta humana. Em face da experiência elaboram-se as ideias para conhecê-la. Essas ideias são os primeiros interpretantes lógicos dos fenômenos que os sugerem, e na medida em que os sugerem, são signos. Daí vem que a percepção nada mais é do que interpretação de dados sensores desconexos que são organizados com base em hipóteses cognoscitivas em experiências anteriores (ECO, 2003, p. 145). Agora, ao ter sua determinação ligada à conduta humana sobre as quais atua, o significado conquista, com Peirce, uma dimensão social: o significado não é uma ideia que o símbolo evoca na mente, mas consequência da conduta que gera nos humanos racionais e que vem suportado pelo símbolo, via construção socialmente convencionada.

Esses fundamentos fazem com que Peirce classifique o significado em três espécies distintas: Interpretante Imediato, Interpretante Dinâmico e Interpretante Final. Grosso modo, o primeiro interpretante diz respeito ao significado que está em causa no momento em que se comunica um conhecimento que nos procuram dar quando o apreendemos. Este é o grau mais baixo do significado e que se torna algo mais completo quando se leva em conta, para sua determinação, a soma total de todas as predições condicionais pelas quais a pessoa que as utiliza pretende tornarse responsável ou pretende negar. Essa intenção consciente ou quase consciente constitui para Peirce o segundo grau do significado, e que atinge o terceiro e último grau de seu desenvolvimento quando se leva em conta a soma das implicações produzidas pelo signo, que vão desde as mais simples consequências do conhecimento às revoluções na sociedade (COELHO NETTO, 2003, p. 87). Todavia, para cumprir seus objetivos últimos, a prática semiótica peirceana não se detém nas 
etapas intermediárias da formação. Enquanto a permanência no primeiro nível permite apenas a apreensão da acepção do signo, sua mera definição, enfim, sua estrutura mecânica, a passagem para o segundo nível, possibilita a captação do significado, fornecida pela intenção constante existente por detrás do signo. Mas, somente com a chegada ao nível de significação dá-se por determinado o signo, isto é, a chegada ao nível mais profundo e elevado da existência do signo, o nível do Interpretante Final. E relembrando, o significado próprio a alcançar do signo é a forma pela qual a proposição se torna aplicável à conduta humana, não nestas ou naquelas circunstâncias especiais, mas nas formas mais diretamente aplicáveis ao autocontrole em todas as situações, em todos os propósitos e na descrição geral dos fenômenos experimentais que a asserção da proposição venha a predizer.

Como o signo determina o interpretante, este é uma propriedade objetiva que aquele possui em si mesmo ao originá-lo. O interpretante é uma criatura do signo que, em última instância, não depende do modo como uma mente subjetiva, singular, psicológica venha a compreendê-lo, apesar de serem possíveis atos interpretativos particulares, isto é, interpretações individuais (SANTAELLA, 1995, p. 85). Desta forma, o signo, para Peirce, é sempre um tipo lógico, geral, muito mais geral do que um existente intérprete possa dele fazer uso.

A tríade peirceana diz respeito aos níveis ou graus ou estados por que passa o interpretante até se converter em outro signo, caminhando para o interpretante (Final) em si. Essa classificação do interpretante habilita Peirce a aprofundar o processo de sua geração, por meio de uma análise específica dos momentos lógicos da relação entre signo e interpretante. Em concordância com isso, enquanto o primeiro e o último interpretante da tríade são concebidos por ele "in abstrato", porém, o interpretante intermediário o é "in concreto". Essa diferença deve-se as suas construções que são explicas por SANTAELLA $(1995$, p. 102) da seguinte maneira. O Interpretante Dinâmico é o fato empírico do significado psicológico ou resultado factual do entendimento do signo. É o movimento de transformação do pensamento (signo) que se realiza efetivamente, suportado por eventos reais de interpretação. O Interpretante Imediato é uma mera possibilidade para significar, ou de sentido do signo ainda não revelado, mas que está inscrito nele de modo vago e indeterminado. É, conforme a palavras da autora, "pura potencialidade, interpretabilidade ainda não-realizada" (sic), não obstante, contida na natureza do próprio signo. Trata-se do teor daquilo que o signo é capaz de significar. É o efeito sugestivo não analisado que o signo foi calculado para 
produzir (COELHO NETTO, 2003, p. 75, 88). O Interpretante Final, por sua vez, é o limite último, se isso fosse possível, de realização completa de uma interpretação verdadeira, caso se considerasse o assunto de um modo tão profundo, que se pudesse chegar a uma opinião definitiva (ibid., p. 71). É a definição gerada pelo hábito, o verdadeiro e final interpretante lógico. É a confirmação mais perfeita de um conceito que as palavras poderiam veicular, consistindo na descrição do hábito que o conceito está destinado a produzir (ECO, 1985, p. 145). É, enfim, um limite ideal, abstrato, de uma direção que o real tende, não dependendo estritamente de cada Interpretante Dinâmico efetivo. Este último é produzido via concretização singular e particular de atualizações mais ou menos adequadas da interpretabilidade do signo, rumo ao limite abstrato e ideal para o qual todos os Interpretantes Dinâmicos tendem mais cedo ou mais tarde, por erros e acertos, por caminhos que não se podem, de antemão, estipular. Uma atualização particular ou psicológica do Interpretante Dinâmico é sempre necessária, mas relativa e sujeita à correção e à crítica. Correção somente possível devido à relação dialética entre a potencialidade inscrita no signo pelo Interpretante Inicial e o limite ideal do Interpretante Final para o qual as atualizações singulares assintoticamente se dirigem (SANTAELLA, 1995, p. 102). Logo, assim se apresenta o mecanismo que envolve a ideia de signo à luz de Peirce, e que fundamenta o seu conceito de significado.

Dando fechamento ao abordado, e principalmente com o objetivo de deixar a próxima discussão mais bem contextualizada no que se refere às implicações práticas para a educação científica, vale explicitar uma menção de SANTAELLA (1995). Segundo ela, os interpretantes podem ser "tocados", uma vez que as existências das unidades culturais podem ser verificadas por meios físicos. "As unidades culturais são abstrações metodológicas "materializadas", posto que a cultura continuamente traduz signos em outros signos, definições em outras definições, palavras em ícones, ícones em signos ostensivos, signos ostensivos em novas definições, novas definições em funções, proposições, estas em enunciados exemplificativos e assim por diante, em uma cadeia ininterrupta de unidades culturais que compõem outras unidades culturais" (ibid., p. 60-61); enfim, todas passíveis de perscrutação pelo professor.

\section{NÍVEIS INTERPRETANTES DA APRENDIZAGEM CIENTÍFICA}

Divisando o campo semântico da linguagem científica como um grande signo complexo, constituído por símbolos, fórmulas, definições, princípios, ideias, conceitos, modelos, teorias, 
procedimentos etc., passemos para a apresentação de uma proposta analítica que visa estabelecer a significação, como um fenômeno diacrônico da aprendizagem ocorrida nos estudantes, quando estes se veem em atividades de ensino para aprender os signos científicos.

Em se tratando, então, da aprendizagem das ciências, uma questão capital para o professor referese à possibilidade de acompanhar a produção e o desenvolvimento dos significados que os estudantes vão adquirindo durante o processo de ensino, com o objetivo de direcioná-los e enquadrá-los ao conhecimento científico. A fim de buscar uma solução nesse sentido redirecionamos os conceitos de Interpretantes da teoria semiótica de Peirce acima, apropriando-os para os objetivos pedagógicos aqui desejados.

Recordando que Peirce (apud. SANTAELLA, 1995, p. 104), ao colocar o problema do que seja o significado de um conceito intelectual, afirma que a sua solução passa pela ideia dos interpretantes ou, mais propriamente, dos efeitos interpretantes dos signos, em que este é parte constituinte do signo que afeta a mente, determinando ou criando-Ihe um efeito. Com esse conceito, estabelece que o processo de significação é sempre contínuo, crescente e dirige-se para o conteúdo objetivo do signo. Conhecer qual significado é dado a um signo é considerar que efeitos interpretantes são concebidos frente ao objeto da percepção. Decorrente da concepção desses efeitos resulta a constituição do conjunto da nossa concepção do que seja objeto (cf. também, FIDALGO; GRADIM, 2005, p.123).

Identificar níveis ou graus interpretantes que especifiquem o estado momentâneo do significado do conhecimento do aprendiz é um projeto desejável e realizável na medida em que se abre a possibilidade de estabelecimento de um paralelismo com os três níveis interpretantes peirceanos. Para que essa realização se concretize propomos uma reformulação da tricotomia interpretante, adequando-a para uma leitura com fins pedagógicos. Por isso, a transposição dos termos técnicos peirceanos com esses objetivos, ao mesmo tempo em que nos liberta de uma maior fidelidade e rigor de seus conceitos, obriga-nos um distanciamento seguro de seus condicionantes sem tornar suas origens irreconhecíveis. Isto se impõe, dada à conformação diferenciada e particular existente em qualquer situação factível de ensino e de interesse pedagógico, que exige um afastamento das demarcações e enunciações dos estatutos eminentemente lógicos de Peirce. Parte integrante do movimento e transformação do pensamento do aprendiz em atividade de ensino, o instituto 
interpretante aqui pretendido tem a intenção de caracterizar os significados da aprendizagem dos estudantes sem literalidade, mas por correspondência ou afinidade com as proposições colocadas por Peirce. Logo, reforçando, o inevitável afastamento das ideias strito sensu peirceanas se dá pela impossibilidade de reduzi-las a uma concepção estreita, circunstancial ou situacional ligada a possíveis e imagináveis problemáticas educacionais que normalmente são de interesse do professor, razão da necessidade da leitura particular.

Ponderado isso, pode-se começar a pensar um primeiro resultado do ato de significação estabelecido por um aprendiz frente aos signos científicos como qualificado de Interpretante Imediato. Este se caracteriza pelo estabelecimento de um efeito interpretante que o signo causa no sujeito e que ainda não se encontra atualizado por meio da instrução pretendida. Somente aspectos vinculados à denotação de primeira ordem se tornam presentes e a interpretação acaba permanecendo presa ao significado interno e ordinário do signo. Com denotação de primeira ordem, conforme visto, se está a opor uma semiótica conotativa que deve ser produzida mediante ensino, cujo plano da expressão se vai constituir de outra semiótica, de forma que o significado lhe corresponda em segunda instância. O significado da unidade cultural de primeira instância, do qual se compõe e identifica as marcas denotativas de primeira ordem, é a base para conotações sucessivas ou, de maneira direta, denotações científicas (denotações de segunda ordem). Por exemplo, a marca conotativa (denotação de segunda ordem) dos signos "trabalho" ou "respiração vegetal", respectivamente, dentro do contexto da Física ou da Biologia, ultrapassa a marca denotativa de primeira ordem, da primeira impressão ou concepção de senso comum, que corriqueiramente é empregada pelo leigo em sua vida diária.

Assim, anterior a qualquer ato instrucional provocado, o significado contido no signo é aquele corriqueiro que aparece, à primeira vista, ao sujeito. É o efeito interpretante pertinente, possível e imediato na sua inteireza primitiva não escolarizada. A interpretação se faz direta, literal, no sentido de não ser objeto de qualquer tipo de análise ou reflexão mais pormenorizada, mostrandose compartilhada por aqueles que mantêm confluentes estados prévios de conhecimentos. O nível interpretante é prioritariamente icônico ou de índice (ECO, 2003, p. 157), posto que ambos mantêm relação direta com os estados do mundo, sendo que a relação do primeiro é de semelhança com o objeto figurado, não havendo um desprendimento maior deste, enquanto o segundo a relação se apresenta de dimensão existencial e causal elementar. O Interpretante 
Imediato permanece circunscrito ao contexto dos conhecimentos prévios do aprendiz, das concepções baseadas no aparente, no intuitivo, no senso comum. As impressões extraídas do signo e suas possíveis reflexões se sustentam na ausência de provocação de elementos analíticos novos do qual o lócus instrucional é fomentador.

Ultrapassando, por transformação de ordem conotativa, o nível Interpretante Imediato, o segundo nível de significação, denominado Interpretante Dinâmico, refere-se ao efeito interpretante que o signo provoca em uma mente que se vê estimulada por interferências de ensino. No Interpretante Dinâmico, o processo de conotação sígnica é desencadeado e deslocado da denotação de primeira ordem em razão de novas significações que começam a se instaurar na mente por causa da circunstância instrucional. Fala-se agora em conotação ou denotação de segunda, terceira etc. ordem, já que o significado provém, respectivamente, de segundos, terceiros etc. sentidos assentes sobre a primeira denotação (ECO, 1985, p. 90; PRESMEG, 2006, p. 166; BARTHES, 1989, p. 189), cuja significação original se mantinha no nível Interpretante Inicial. Em outras palavras, no Interpretante Dinâmico aquilo que é experimentado por acúmulo ou transformação de significações, em virtude de momentos instrucionais variados, vai-se tornando gradualmente diferenciado do Interpretante Imediato. O efeito interpretante permanece dependente do maior ou menor grau da apropriação de novos conhecimentos pelo aprendiz e de uma relação subjetiva mais ou menos extensa com eles, por isso, tal efeito interpretante tem característica provisória, transitória, vaga, falível, incompleta, conforme a profundidade ou influência do conteúdo aprendido. Quanto aos efeitos interpretantes produzidos no intérprete, o Interpretante Dinâmico subdivide-se em Emocional, Energético e Lógico, sendo que a relevância relativa do significado de cada um desses três interpretantes mantém-se na dependência do tipo de conteúdo tratado. Assim, um simples e primaz efeito semiótico que um signo pode vir a ser capaz de provocar em um intérprete pertence à qualidade mais ou menos vaga de sentimento, da dimensão do sensível ou mesmo metafísica. Desta forma, o efeito Interpretante Emocional confunde-se com a potencial carga emocional ou transcendental proporcionada pelo signo, que vem acompanhada por uma atitude valorativa, positiva ou negativa, somada a uma insipiente combinação com o conhecimento ensinado na tentativa de articulá-lo. Nesse Interpretante, poder-se-ia dizer que prevalece a função de ordem estética do signo (EPSTEIN, 2002, p. 33, 34), própria dos signos artísticos. Estes jogam com a violação da norma (ECO, 2003, p 224), com a inesgotabilidade dos sentidos, sendo que a todo o momento, para diferentes receptores, ou para o mesmo receptor em momentos diversos, 
sempre apresentam um conteúdo diversificado, não se podendo falar, portanto, num interpretante final de comum compartilhamento. Daí vem significados contraditórios, opacos, indeterminados, ambíguos, hesitantes, presos à beleza e opiniões emocionais, metafísicas e transcendentes, de caráter religioso, místico ou mítico. Significados que se vêm envoltos em sensações, sentimentos e valores, dado que a leitura do signo tende a avocar maior atenção para estados subjetivos e incertos do que para o conteúdo instrucional lógico, formal, normativo e impessoal que pode, por associação, vir a ser extraído por detrás dele. Há, por consequência, condescendência com uma lógica próxima ao do milagre, do mistério, pois suas máximas não surgem para ser compreendidas, mas apreendidas por revelação ou contemplação, uma vez que suas verdades são inacessíveis à razão, logo, no limite, inexplicáveis. O efeito Interpretante Emocional permanece na dependência da representação semiótica confrontada possuir maior ou menor marca conotativa emocional vis a vis ao tipo de conteúdo tratado. Deste modo, quando em processo de ensino de certos conteúdos científicos o aprendiz mescla ou dá destaque a argumentos de domínio não científicos, devido à possibilidade de correlação com o tema em foco. Alguns exemplos a imaginar de conteúdos no ensino das ciências que poderiam propiciar e estimular um nível Interpretante Emocional seriam: darwinismo versus design inteligente; experimentos com células embrionárias ou animais; organismos geneticamente modificados; conservação ambiental; conceitos de força e trabalho de Física como alusão a vigor corporal ou labor, respectivamente; origem da Terra ou universo versus concepções deístas.

Vale esclarecer que o Interpretante Emocional é o efeito interpretante produzido pelo signo que está por detrás de um conteúdo científico específico. Isto significa dizer que ele precisa ser compreendido a partir do enquadramento do conteúdo em foco, em vez de genéricos estados de sentimento ou disposição psíquica de emoção, afetividade, desejo, motivação, ansiedade, vontade de estudar, crença de autoeficácia, antipatia pelo professor etc. Quando tais qualidades não permanecem circunscritas a fatores de ordem exclusivamente psicológicos, mas provocadas pelo que o signo significa para o sujeito, com consequente interferência cognitiva ligada ao conteúdo, ao Interpretante Emocional é genuinamente atribuído essas qualidades.

O Interpretante Dinâmico Energético, por sua vez, é o efeito significado revelador da qualidade ou disposição da apreensão conceitual demonstrada através de atos concretos de interpretação, levando a ou traduzindo-se em "esforços musculares". No nível Energético, a ação física, reflexo de 
uma ação interiorizada, toma parte integrante do efeito significado. Do ponto de vista dessa ação se traduzem comportamentos, atitudes, procedimentos e técnicas originados do processo educacional, ainda que seja comum todos eles se apresentarem, de início, um tanto quanto metódicos, mecânicos ou estritamente fixos. Sua correspondência com o hábito, ato ou manipulação leva a resposta comportamental a despender alguma energia em relação ou reação ao mundo, tanto material, como social. Da reação originada da autoidentidade particular dos objetos físicos que agem sobre nós e sobre os quais agimos ou influenciamos, oferecendo, muitas vezes, resistência às manipulações, surge a necessidade, frente aos conhecimentos científicos, de criar novos atos, hábitos ou comportamentos sociais. Todos estes se transformam, quando a autoidentidade do mundo interior, constituída pelas fantasias, imagens ou representações mentais (DUVAL, 2004, p.35-37) do sujeito, deixa de ser recalcitrante à mudança por apropriação do novo conhecimento. É corriqueiro o Interpretante Dinâmico Energético se apresentar via emissão de signos expressivos visuais (ECO, 1985, p. 38), os quais não têm a intenção direta de comunicar, pois costumam ser espontâneos, involuntários e intuitivos, visto escaparem à codificação consciente. Esses signos expressivos aparecem de forma subliminar nas ações ou gestos existentes nos comportamentos, atitudes, procedimentos e técnicas. Todavia, quando emitidos intencionalmente, se corretos ou incorretos, tornam-se signos comunicativos (ibid.), visto terem sido produzidos artificialmente, no sentido de provocados por meio da instrução. Então, dos signos emitidos através da ação, atos, gestos, expressões etc. decorrem os efeitos significados de nível Energético.

O Interpretante Dinâmico Lógico é o efeito significado que se mostra expresso junto aos signos comunicativos em meio a regras interpretativas formais e normativas que têm por base o conteúdo eminentemente conceitual. Este efeito interpretante se dá por função semântica e base sintática, estando associado aos modos de expressão, significado e sentido dos termos e símbolos utilizados pela nova concepção e que permite construir e identificar representações, imagens e proposições coerentes, internamente consistentes e inter-relacionadas. O signo é interpretado através do domínio de novas regras internalizadas pelo intérprete que auxiliam a fazer inferências e estabelecer consequências de premissas. Tais regras, de natureza associativa, de classe e relações hierárquicas, conectam o signo a outros objetos e signos do conhecimento científico de maneira unívoca, sem admissibilidade de equívoco, em que as questões valorativas são capazes de permanecer isoladas para fins inteligíveis. Opostos aos signos de função estética, os quais preparam estados psicológicos, evocam emoções, são de difícil tradução de uma linguagem para 
outra, seus significados tornam-se mais opacos, a incerteza permanece inerente a sua constituição, já que chamam a atenção para si, para sua forma e materialidade, os signos da linguagem técnica ou científica, por outro lado, são construídos para serem estritamente lógicos. Ou seja, são rigidamente estruturados, traduzíveis e demandam respostas ativas dirigidas a objetivos explícitos, por isso, mantêm acentuada função semântica. Concernente à determinação precisa do significado, tal função prepara para a ação, portanto, para a observação, experimentação e conduta precisa, motivo pelo qual esses signos têm que ser únicos, em termos do compartilhamento de seu significado, para facilitar a comunicação e conferir ou ratificar as teorias propostas (EPSTEIN, 2002, p. 33, 34).

A princípio, esses signos unívocos (ECO, 1985, p. 46) usados na ciência, ao preparem para ação objetiva, não deveriam ter dissociados seus efeitos interpretantes Lógico e Energético. De fato, os três níveis interpretantes dinâmicos coexistem com predominância relativa entre si, estando suas prevalências na dependência da evolução do entendimento alcançado, da natureza ontológica do tema tratado e da relação que mantêm com as características tipológicas do conteúdo que está sendo estudado, seja ela conceitual, procedimental ou atitudinal (ZABALA, 1998, p. 30).

Frente ao objeto do conhecimento direcionado pelo ensino, o Interpretante Final é o último efeito interpretante, idealizado pelo professor e balizado pelo currículo, cujo destino do entendimento todo intérprete deveria alcançar, após o desenvolvimento suficiente do seu pensamento a respeito do conhecimento científico ensinado. Nele, o nível interpretante é de tal ordem de significação que o signo apreendido torna-se parte integrante de um conhecimento normatizado. É o momento em que o mundo dos enunciados objetivos de um discurso racional e crítico científico encontra-se dominado. O Interpretante Final, em contraste com os anteriores, independe de um intérprete particular e corresponde à convergência de sentidos intermentais que se encontram enquadrados pela comunidade científica. Sua objetividade se mostra de natureza coletiva, não se restringindo e ficando independente de humores, fantasias ou crenças pessoais ou transcendentais de um intérprete em particular. Um pleno estado Interpretante Final, cuja demarcação relativa é fixada pelo conhecimento destinado dentro dos objetivos do ensino, aparece quando o signo determina em quaisquer mentes, condutas e desempenhos semelhantes; aqui se evidencia o traço social e compartilhado do efeito interpretante e que vai além do lógico. 
Uma interpretação particular, psicológica, dos interpretantes Imediato e Dinâmico, posto que inacabada, constantemente passa por uma necessária atualização, sujeitando-se à correção e à crítica, a fim de atingir, após longo percurso instrucional, o Interpretante Final. Decorre, então, que este interpretante não consiste no modo pelo qual qualquer mente particular realmente age e pensa, mas no modo pelo qual toda mente deveria agir e pensar em conformidade com o conhecimento oficial. Em tal grau interpretante, o intérprete alcança autonomia para fins de articulação dos seus enunciados, proposições, teorias, ideias e ações. Nele, a demonstração de um real entendimento se faz pela exposição da capacidade de mobilização consistente de conceitos, habilidades e condutas, mesmo que o intérprete se veja confrontado com exemplos ou situações novas. Particularmente, há mudança efetiva de hábitos, haja vista que o controle crítico brota do pensamento sob ângulos originais e diversos. Crenças petrificadas são desalojadas, inaugurando novos modos de conduta e ações cognitivas. O entendimento é apreciado pela conjunção coordenada dos interpretantes Lógico e Energético, e pela convivência harmônica, ou ao menos não mais conflituosa, do ponto de vista do aprendiz, com o Interpretante Emocional. A ressignificação conquistada ao nível do Interpretante Final é esperada reportar-se à esfera da convicção, posto haver integração, por transformação consistente, dos efeitos da tríade do Interpretante Dinâmico, em que a mensagem final se torna sobrecódigo em relação ao código do signo originário do Interpretante Inicial. Da integração coordenada entre o conhecer conceitual, o crer, o saber fazer procedimental e atitudinal, o efeito Interpretante Final de um aprendiz pode ser avaliado pela produção de inferências, avaliações, generalizações, seleções, comparações e realizações aplicáveis do efeito desejado, mas dirigido para um fim concreto ou em ato de imaginação, não mais de maneira ritualizada, estritamente fixa e incompreensível.

O efeito significado terminal é o destino do caminho interpretativo conquistado por meio da apropriação cultural, como colocado. Alcançar o Interpretante Final é, em síntese, atingir a meta de desprendimento do aspecto denotativo de primeira ordem do signo e estabelecer análises conotadas com foco, não no que é percebido e pensado de modo aparente ou vulgar, mas no que está institucionalizado pelo signo. O signo, neste caso, passa a pertencer à categoria símbolo, por conseguinte, é normatizado em uma nova denotação. Assim, signos icônicos, como os exemplificados pelas grandezas baseadas nos significantes "força" ou "trabalho", em que prevaleciam primitivas e desvirtuadas relações de semelhança com ideias cotidianas, são, a partir de agora, tão somente suportes para balizá-lo em denotações ressignificadas de enésima ordem, 
em que o tema dominante se torna capturado pelos conceitos oficiais. Enfim, quaisquer outros signos ou situações novas e desconhecidas analisadas "a posteriori" são igualmente interpretados por critérios institucionalizados, com generalização discursiva que vai além da reprodução literal de enunciados, logo, mostrando genuína compreensão pessoal. A significação completa atingida pelo Interpretante Final de um sujeito reúne todos os efeitos interpretantes que o professor tem em vista, vindo da somatória das lições acerca do signo, dos resultados capazes de afetar a conduta e dos objetivos pretendidos para com o aprendiz.

\section{CONSIDERAÇÕES FINAIS}

De forma geral, a natureza do significado pode ser compreendida como um estado de consciência (OGDEN; RICHARDS, 1989, p. 179). No caso de um aprendiz, frente a um signo científico, esse estado se confunde com o entendimento dado ao conhecimento ensinado. Ao realizar um olhar semiótico para o significado, o trabalho procurou conceituá-lo segundo uma reformulação dos Interpretantes de Peirce. Como se sugeriu, no decorrer da apropriação simbólica, produzem-se na mente do aprendiz efeitos interpretantes distintos. Na prática escolar, eles podem ser apreciados mediante o desempenho e atitudes exigidos nas tarefas envolvidas com as diversas tipologias de conteúdo (ZABALA, 1998), que se encontram inerentes, mas que também são relativos ao conhecimento científico estudado.

O construto analítico para identificar estados de significação alcançados pelos sujeitos em escolarização de conteúdos das ciências, motivado pela reformulação peirceana, tem como objetivo proporcionar ao professor uma orientação teórica para qualificar o significado apropriado por seus estudantes. Além disso, a elaboração deste instituto oferece a ele uma leitura alternativa à forma de compreender a questão do significado dado à aprendizagem. No entanto, a sua validação, fecundidade ou eficácia analítica passa pela viabilidade de se conseguir executá-lo no espaço da sala de aula. Assim, a motivação para a continuidade deste estudo encontra-se na superação de possíveis desafios de transformar a proposta teórica em uma ferramenta analítica aplicável em alunos reais, projeto que estamos dando início.

Conscientes de que a reflexão desenvolvida trata-se de uma particular perspectiva a respeito da complexa questão do significado, entendemos que ela não se apresenta como algo fechado e 
obrigatoriamente a ser seguido, mas como uma tentativa de resposta, entre possíveis outras, para um problema fundamental dentro do campo da aprendizagem das ciências. Aliás, o compromisso primeiro do trabalho não esteve necessariamente empenhado com a concordância de seus argumentos, mas com sua compreensão e, principalmente, em possibilitar a abertura de novas reflexões de um conceito tão importante para o educador científico e que costuma circundá-lo constantemente em sua profissão.

Apoio CNPq

\section{REFERÊNCIAS}

AUSUBEL, D. P.; NOVAK, J. D. \& HANESIAN, H. Psicologia educacional. 2a edição, Editora Interamericana Ltda, Rio de Janeiro, RJ, 1980.

BARTHES, R. Elementos de semiologia, Editora Cultrix, 2ª edição, São Paulo, 1972.

BARTHES, R. Mitologias, Edições 70, Lisboa,1989.

CLEMENT, J. (1982). Student's preconceptions in introductory physics. American Journal of Physics, 50: 66-71.

COELHO NETTO, J. T. Semiótica, informação e comunicação, Editora Perspectiva S.A., São Paulo, 6ạ edição, 2003.

COLL, C. Aprendizagem escolar e construção de conhecimentos. Porto Alegre, Artmed, 2002

DUVAL, R. Semiosis y pensamiento humano: registros semióticos y aprendizajes intelectuales, Universidad del Vale, Instituto de Educación y Pedagogía, Santiago de Cali, Colombia, 2004.

ECO, H. O signo, Editorial Presença, LDA. Lisboa, 1985.

ECO, H. Tratado geral de semiótica. Estudos, Editora Perspectiva S. A., São Paulo, 2003.

EPSTEIN, I. O signo, Série Princípios, 7ạ Edição, Editora Ática, São Paulo, SP, 2002.

FIDALGO, A. \& GRADIM, A. Manual de semiótica, UBI, Portugal, www.ubi.pt, 2005.

GARDNER, H. Inteligências múltiplas, a teoria na prática, Artmed, Porto Alegre, 1995. 
HAND, B.; GUNEL, M. \& ULU, C. Sequencing embedded multimodal representations in a writing to learn approach to the teaching of electricity, Journal of Research in Science Teaching, 46, 3, 225247, 2009.

HIEBERT, J. \& CARPENTER, T. Learning and teaching in the understanding. In D. A. Grouws (Ed.), Handbook of research on mathematics teaching and learning, Reston, VA: National Council of Teachers of Mathematics, 65-97, 1992.

KUBLI, F. Science teaching as a dialogue - bakhtin, vygotsky and some application in th classroom, Science \& Education, 14, 501-534, 2005.

MORRIS, C. Fundamentos da teoria dos signos. Tradução de Antonio Fidalgo, Universidade da Beira Interior, HTTP://bocc.ubi.pt/ fidalgo/semiotica//morris-charles-fundamentos-teoriasigno.pdf, acessado em 29 de junho de 2010.

OGDAN, C. K. \& RICHARDS, I. A. The meaning of meaning, HBJ Harcourt Brace lovanovich, Publishers, USA, 1989, 359p.

OLIVEIRA, M. K. Vygotsky, aprendizado e desenvolvimento. Um processo sócio-histórico. Série Pensamento e Ação no Magistério. Editora Scipione, São Paulo, SP, 1993.

PATTERSON, N. D. \& NORWOOD, K. S. A case study of teacher beliefs of teacher beliefs on students's beliefs about multiple representation, International Journal of Science and Mathematics Education, 2, 5-23, 2004.

PEIRCE, C. Semiótica, Perspectiva, São Paulo, 1977.

PRESMEG, N. Semiotics and the "connections" standard: significance of semiotics for teacher of mathematics, Educational Studies in Mathematics, 61, 163-182, 2006.

PRIETO, L. J. Mensagens e sinais, Editora Cultrix, São Paulo, SP, 1973.

SANTAELLA, L. A teoria geral dos signos: semiose e autogeração, Editora Ática S.A., São Paulo, 1995.

SANTAELLA, L. Semiótica aplicada, Thomson, São Paulo, SP, 2005.

STEINBRING, H. What makes a sign a mathematical sign? An epistemological perspective on mathematical interaction, Education Studies in Mathematics, 2006. 
STERNBERG, R. L. Representação e organização do conhecimento na memória: conceitos, categorias, redes e esquemas. In: Psicologia cognitiva, $4^{\underline{a}}$ edição, Artmed, Porto Alegre, RS, 263293, 2008

VYGOTSKY, L. S. Pensamento e linguagem, Martins Fontes, São Paulo, 2000.

WALDRIP, B.; PRAIN, V. \& CAROLAN, J. Using multi-modal representations to improve learning in junior secondary science, Research in Science Education, 40, 65-80, 2010.

YORE, D. L. \& HAND, B. Epilogue: plotting a research agenda for multiple representations, multi modality, and multimodal representation competency, Research in Science Education, 40, 93-101, 2010.

ZABALA, A. A prática educativa: como ensinar. Artmed, Porto Alegre, 1998. 